\title{
ECONOMIC VIABILITY OF BUSINESS MODELS FOR PHOTOVOLTAIC SOLAR GENERATION IN BRAZIL: STUDIES OF CASES
}

\author{
V. R. Faria ${ }^{1}$, M. L. Magalhães ${ }^{1}$. D. P. Neto ${ }^{1,2}$ and E. G. Domingues ${ }^{1,2}$ \\ ${ }^{1}$ Master Degree in Sustainable Process Technology \\ ${ }^{2}$ Center for Experimental and Technological Studies \\ Federal Institute of Goias, Campus of Goiânia - Goiás (Brazil) \\ e-mails: vitorr.eng@gmail.com,murilo_187@hotmail.com,daywes.neto@ifg.edu.br, prof.eldergd@gmail.com
}

\begin{abstract}
In the last years, worldwide, more capacity of solar energy has been added than any other type of electric power generation technology. The current expansion market is largely due to the increase in market competitiveness of photovoltaic solar energy and demand for electricity. However, the markets continue to be driven largely by government or regulatory incentives and not by innovative business. Therefore, this paper presents: (i) overview of photovoltaic systems regarding the most adopted business models in Brazil; ii) business model economic viability case study. The results presented shows that the acquisition model has the best investment indicators. For the Acquisition and Rental models, all case studies were economically viable, but in the Shared Solar Generation model the Consumer Units $\mathrm{C} 1$ and $\mathrm{C} 2$ were considered unfeasible by Levelized Cost of Energy - LCOE criterion.
\end{abstract}

\section{Key-Words}

Solar Energy, Distributed Photovoltaic Generation, Business Models, Economic Viability.

\section{Introduction}

In recent years, there has been an increase in significant problems related to environmental degradation, greenhouse effect, global warming and the human-caused climate change, which are strongly linked to the growth of energy consumption and the economic development of the countries.

The use of renewable energy sources is growing over the years due to environmental concern, sustainable socioeconomic development, rising oil prices, scarcity of materials for non-renewable energy sources and policies directed at sustainability. The harnessing of energy sources for electricity generation is linked to the technical and economic feasibility analysis and the associated environmental impacts.

In this aspect, Geissdoerfer [1] claims that the ability to move between new business models quickly and assertively is a key competitive advantage in developing the sustainability of a modern organization. More and more companies are committing to the sustainability of their business.

Many definitions have been made for Business Model. According to Huijben, Verbong [2], they are both tools of innovation and competitive advantage for a company. According to Shoettl, Lehmann-Ortega [3], these mechanisms allows the creation of value through a proposition to customers. In other words, Osterwalder and Pigneur [4] believe a business model is how a company creates, delivers and captures value.

This last definition, according to Richter [5] has been extensively tested in practice and has been successful in the field of renewable energy. Therefore, this very definition will be used in this study.

According to Kind [6], the disruptive properties of photovoltaic generation make it stand out from other renewable energy sources, and this justifies the fact of its exponential growth in recent years.

The Renewable Global Energy Status Report published by the Renewable Energy Policy Network for the 21st Century [7] showed that 2017 was a mark for photovoltaic solar energy: the world has added more solar power capacity than any other type of power generation technology. However, markets in most places continue to be driven largely by government or regulatory incentives rather than innovative business models.

The purpose of this paper is to present an overview on photovoltaic systems (PVS) regarding the most adopted business models in Brazil. Then the economic indicators will be calculated and presented, such as Net Present Value - NPV, Internal Rate of Return - IRR, Profitability Index - PI Payback - PB and Levelized Cost of Energy LCOE for study cases in order to determine the viability of the systems. 


\section{Photovoltaic Business Models}

Business models can be applied in any sector and can be used by any organization without restriction. Therefore, several specific business models to photovoltaic generation were developed over time. According to Frantzis et al [8], photovoltaic business models have well-defined generations: Zero Generation, First Generation and Second Generation, as illustrated in Figure 1.

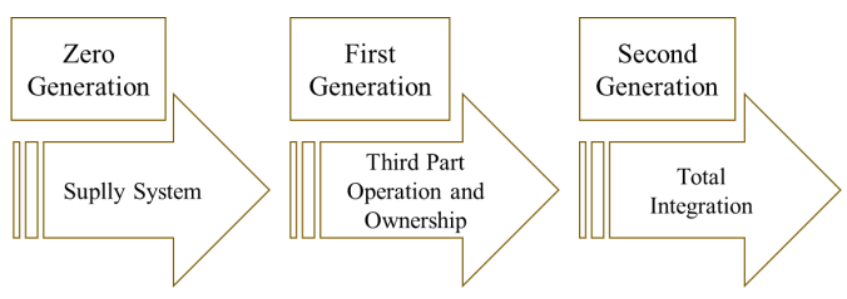

Figure 1 - Business Model Generations for DG - Source (Frantzis et al. 2008 - Adapted)

The Zero Generation business model refers to the first approach of the photovoltaic industry, in which the consumer (end user) owns and finances the system, and manages most aspects related to the installation. The main payment / receipt system between the Distributor and the PV System user (PVS) are the net metering. Brazil is in this generation. The Normative Resolution 482/2012 of April 2012 [9], of the National Electricity Agency (ANEEL) and its NR 687/2015 [10] is the standards responsible for providing access to electricity distribution networks for small generating units.

The First Generation is characterized by the presence of a broader and more attractive market, with a new category of consumers, called early adopters, those who adopt one technology, product or service, before others. A third party who develops the project and owns PVS runs the business models.

The Second Generation of Photovoltaic Business Models is still emerging. The main features of this generation involve the greater integration of photovoltaic systems with the network due to the development of new technologies and regulatory initiatives. Models of this generation allow the system to be an integral part of the distribution segment.

In addition, these resource models show qualities that cover system ownership, operation, and control. This model is used in countries such as Germany and the USA but cannot be used in Brazil yet because the generation, transmission and distribution of electricity in the country are contained in the national interconnected system (SIN) and the concessions belong to the federal government.

The main photovoltaic business models that have been used in Brazil will be presented and discussed below.

\subsection{Acquisition}

The business model for the most traditional photovoltaic solar generation is that of acquisition. In this model the system user is also its financier / investor, owner and responsible for its maintenance and operation [8]. The model fits into Generation zero and is the most widely applied in Brazil today.

The relationships between the actors of this model can be seen in figure 2. The main features of this model are:

a) The investor (consumer) becomes the system owner and enjoys the full value of his economy.

b) There is significant decapitalization due to the initial investment;

c) The monthly expense considers the O\&M costs (operation and maintenance) and the replacement of the inverter;

d) The investor takes the risk of loss of the investment.

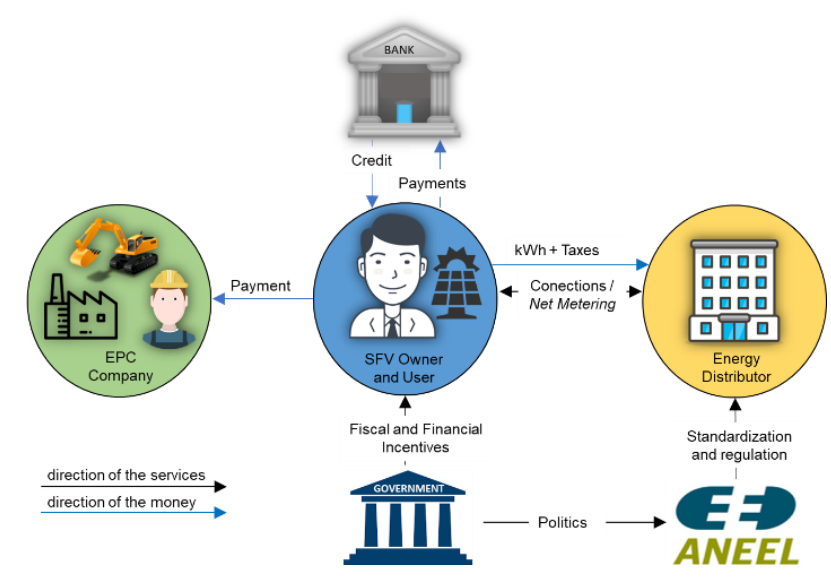

Figure 2 - Relationships in the Acquisition Model (Source: own adaptation)

\subsection{Rent / Third part}

As stated by Huijben and Verbong [11] in the rental model, companies (or third parties) own and operate PVSs installed in consumer buildings. Third parties also rent photovoltaic equipment or sell the energy generated to local occupants where the installation took place. Figure 3 shows the main players of this model, as well as the relationships between them.

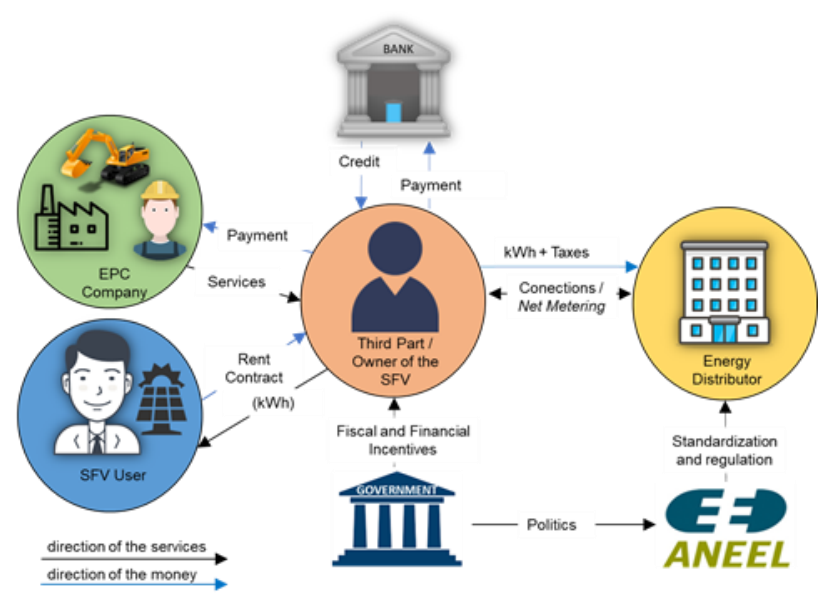

Figure. 3 - Rent Model or third party (Source: own adaptation)

Features in this model includes:

a) The owner is a system tenant; real savings are a percentage of the savings generated by PVS;

b) There is no initial decapitalization of the investor; 
c) The monthly expense considers rent costs and revenues are defined in contract and are generally a percentage value of the energy bill minus the amount of availability cost;

d) The contract is long term, mostly (more than 10 years).

\subsection{Shared Generation}

Shared generation enables several members to unite in a consortium or cooperative to install a micro or minigenerator, using the energy generated to reduce the amounts of electricity bills of the consortium or cooperative [10]. Consumers will have access to the benefits of credits in the same way as consumers that use remote self-consumption, allocating surplus energy to offset the consumption of consumer units (UCs) that integrate distributed generation. Figure 04 illustrates the schematic of a shared way photovoltaic generation system.

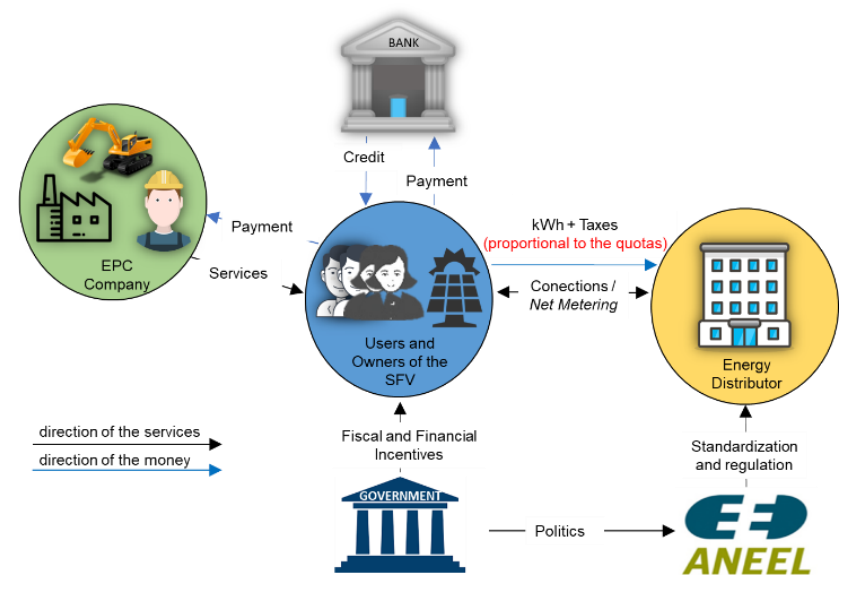

Figure 04 - Shared generation model (Source: own adaptation)

The main features of this model are:

a) The investor (final consumer) owns a part of the system, proportional to their shares/fraction of the business enterprise.

b) The investor enjoys the value of his share in the total savings of the system;

c) There is no significant decapitalization due to the initial investment;

d) Monthly expense considers O\&M costs.

e) The members (end customers) take the risk of loss of the investment.

\section{Economic Viability Indicators}

The Net Present Value (NPV), presented in equation (1), is the indicator that calculates the present value of a series of future financial movements, discounted at a minimum attractiveness rate of return (MARR), considering the initial investment and revenues and expenses over time. NPV indicates the potential for value generation. Therefore, if NPV is positive, the investment will bring positive result [12].

$$
N V P=-I N V+\sum_{t=1}^{T} \frac{\left(R_{t}-D_{t}\right)}{(1+i)^{t}}
$$

Where in (1): INV represents the initial investment; Rt and Dt represent sources of income and expenses over period $t$;
$T$ is the project life and $i$ is the minimum project attractiveness rate.

The Internal Rate of Return (IRR), given by equation (2) is the interest rate that makes the net present value (NPV) of cash flow equal to zero. In other words, it is the investment projected return estimating how much one wishes to execute a project according to the defined cash flow. Investments with IRR greater than MARR are considered profitable and are subject to analysis [12].

$$
0=-I N V+\sum_{t=1}^{T} \frac{\left(R_{t}-D_{t}\right)}{(1+i)^{t}}
$$

The payback period or Discounted Payback (PD) is the period of time when the return on investment occurs, considering the value of money over time, being calculated in the cash flow of the investment's useful life [13]. This indicator should not be considered alone for decision making as it depends on the time the investor wishes to take the investment back.

The profitability index (IL) can be used by (3) and represents a percentage of compensation for each currency unit invested, so an alternative that has a higher level of profitability is preferred, as long as it is positive.

$$
\mathrm{IL}=\sum_{t=1}^{T} \frac{\left(R_{t}-D_{t}\right)}{(1+\mathrm{i})^{t}} / I N V
$$

The Levelized Cost of Energy (LCOE), given by equation (4), represents the cost of $\mathrm{kWh}$ generated by the photovoltaic system. This indicator is compared to the value of the electricity tariff to determine the tariff parity [14]. PVS LCOE should be lower than power tariff.

$$
\mathrm{LCOE}=\frac{I N V+\sum_{t=1}^{T} \frac{C_{t}}{(1+i)^{t}}}{\sum_{t=1}^{T} \frac{E_{f v}}{(1+i)^{t}}}
$$

Where in (4): $C t$ and $C t$ represent the PVS costs in period $t$ and $E f v$ the energy generated by PVS in $\mathrm{kWh}$, respectively.

Table 01 presents a summary of all indicators, as well as their acceptability criteria that will be used in the economic viability analysis of photovoltaic systems in each of the case studies.

Table 01 - Economic indicators and acceptability criteria

\begin{tabular}{|c|c|c|}
\hline Indicator & Situation & Acceptability criteria \\
\hline \multirow{3}{*}{ NPV } & NVP $>0$ & Project will be accepted \\
\cline { 2 - 3 } & NVP $=0$ & Project can be accepted \\
\cline { 2 - 3 } & NPV $<0$ & $\begin{array}{c}\text { Project will not be } \\
\text { accepted }\end{array}$ \\
\hline \multirow{2}{*}{ IRR } & IRR $>$ MARR & $\begin{array}{c}\text { Project cannot be } \\
\text { accepted }\end{array}$ \\
\cline { 2 - 3 } & IRR $\leq$ MARR & Project will be rejected \\
\hline \multirow{2}{*}{ Payback } & \multicolumn{2}{|c|}{$\begin{array}{c}\text { Smaller than lifespan will be accepted. } \\
\text { Greater than lifespan will be rejected. }\end{array}$} \\
\hline
\end{tabular}




\begin{tabular}{|c|c|}
\hline IL & IL $>0$ \\
\hline LCOE & Should be less than the power rate \\
\hline
\end{tabular}

\section{Metodology}

Figure 5 presents the general flowchart of the methodology used for the economic viability analysis of the photovoltaic business models presented in this paper.

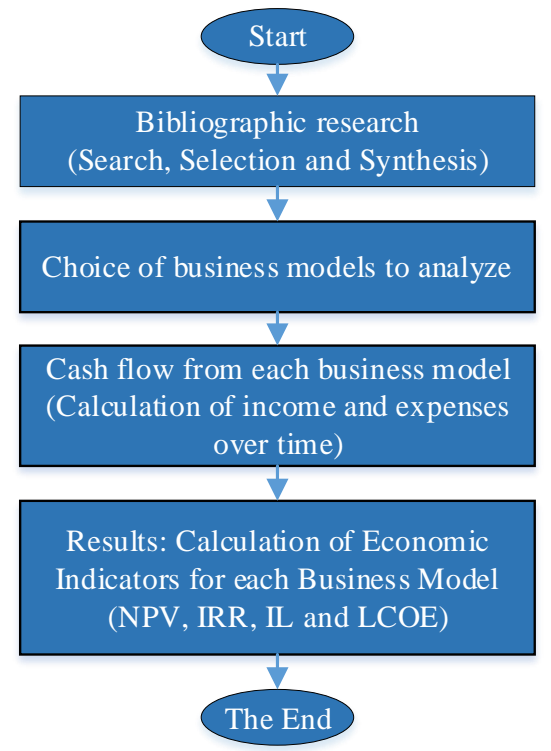

Figure 05 - Methodology used for the economic viability of business models.

\subsection{Systematic literature review}

The first step of the methodology in conducting a systematic literature review, consulting articles, journals and books on the subject. Throughout the process some were selected for the study and then separated and stored for future analysis in a database. With this database, a synthesis of all knowledge was performed.

\subsection{Choice of Business Models}

The second step is the choice of business models to analyze. Among the various business models, three (3) were chosen for the economic viability study, namely, Acquisition, Rental/Third Part and Shared Generation. These models were chosen because they are the most representative in the literature, as well as representing all generations of business models for PVS.

\subsection{Cash Flow for Each Business Model}

The next step is to obtain cash flows for each business model, which consists of obtaining sources of income and expenses over the project's lifespan.

\subsubsection{Acquisition}

Revenues and expenses over time for the acquisition business model can be derived from equations (5) and (6) [15].

$$
\begin{gathered}
R_{a q t}=P_{f v} * E(i m a) *(1+E(v i a)) * E(P R) *\left(1-E\left(q_{r}\right)\right) \\
* T_{e} *(1+E(R p e)-E(i f c))
\end{gathered}
$$

$$
\begin{gathered}
D_{a q t}=E(O \& M) * I N V+E(N T I) * P I+C D * T_{e} \\
*(1+E(\text { Rpe })-E(\text { if }))
\end{gathered}
$$

Where in (5), $R_{\text {aqt }}$ represents the revenues in period $t, P_{f v}$ the Power of the FVS in $\mathrm{kW}, E(\mathrm{ima})$ is the expected value of the average annual irradiance in full sun hours; $E$ (via) the expected value of the interannual variance, $E(P R)$ the value of the performance ratio, $E\left(q_{r}\right)$ the value of the FVS yield drop, $T_{e}$ the energy tariff in reais, $E$ (Rpe) the price adjustment of energy and $E(i f c)$ inflation.

Where in (6), $D_{a q t}$ represents the expenses in period $t, E(O \& M)$ operating and maintenance costs, INV the investment value, $E(N T I)$ inverter exchange number, $P I$ price of the inverter, $C D$ cost of availabilities, $T_{e}$ the energy tariff in reais, $E(R p e)$ the price adjustment of energy and $E(i f c)$ inflation.

The cash flow for the acquisition model is defined by equation 7.

$$
F C_{a q t}=-I N V+\sum_{t=1}^{T} \frac{R_{a q t}-D_{a q t}}{(1+i)^{t}}
$$

Where in (7), $F C_{a q t}$ represents the cash flow of the acquisition model in Reais in the period, INV the initial investment, $R_{\text {aqt }}$ the acquisition model revenues, $D_{a q t}$ the acquisition model expenses and $i$ is the MARR.

\subsection{2 - Rent / Third Part}

In the third party business model, the initial investment is zero for the user and the revenues are the same as the acquisition business model presented in equation (5); however, expenses are represented by the availability cost plus the rental amount, as shown in Equation 8 [15].

$$
D_{a g t}=A G * R_{a g t}+C D * T_{e} *(1+E(R p e)-E(i f c))
$$

Where in (8), $D_{\text {agt }}$ represents expenses in period $t, A G$ the percentage of rent, $R_{\text {agt }}$ the revenues in the rental model, $C D$ availability cost, $T_{e}$ the energy tariff in reais, $E$ (Rpe) the price adjustment of energy and $E$ (ifc) inflation.

\subsection{3 - Shared Generation}

The shared energy model is similar to the acquisition model, with a single difference, revenues and expenses are multiplied by a factor that corresponds to the percentage agreed in the contract, which, as a rule, is proportional to the own quota of the member.

The savings generated by the photovoltaic system are a portion of the investor's monthly energy consumption, as shown in equations 9 and 10 below.

$$
\begin{gathered}
R_{a q t}=P_{f v} * E(\text { ima }) *(1+E(\text { via })) * E(P R) *(1- \\
\left.E\left(q_{r}\right)\right) * T_{e} *(1+E(\text { Rpe })-E(\text { if })) * F_{c u} \\
D_{a q t}=(E(O 9) \\
\\
*(1+E(\text { Rpe })-E(\text { if }))
\end{gathered}
$$


Where in (9), $R_{a q t}$ represents the revenues in period $t, P_{f v}$ the Power of the FVS in $\mathrm{kW}, E$ (ima) is the expected value of the average annual irradiance in full sun hours; $E$ (via) the expected value of the interannual variance, $E(P R)$ the value of the performance ratio, $E\left(q_{r}\right)$ the value of the FVS yield drop, $T_{e}$ the energy tariff in reais, $E$ (Rpe) the price adjustment of energy, $E$ (ifc) inflation and $F_{c u}$ the factor proportional to the quotas of the consuming unit.

Where in (10), $D_{a q t}$ represents the expenses in period $t, E(O \& M)$ operating and maintenance costs, INV the investment value, $E(N T I)$ inverter exchange number, $P I$ price of the inverter, $C D$ cost of availabilities, $T_{e}$ the energy tariff in reais, $E$ (Rpe) the price adjustment of energy and $E$ (ifc) inflation and $F_{u c}$ the factor proportional to the quotas of the consuming unit.

\section{Results}

The choice of consumer units was made according to the convenience sample, where individuals to apply the methodology are readily accessible. In this sense, for the case studies of the acquisition and rental models, two consumer units located in the city of Goiânia-GO were chosen, both with supply below $2.3 \mathrm{kV}$, that is, belonging to Group B, one of the sub- group B1 (low voltage, residential) and another of B3 (low voltage, commercial).

Table 2 - Consumer Profiles - Cooperative Simulator

\begin{tabular}{|c|c|c|c|}
\hline $\begin{array}{c}\text { Quant } \\
\text { ity }\end{array}$ & $\begin{array}{c}\text { Average } \\
\text { Cons }\end{array}$ & Description & $\begin{array}{c}\text { Consumer } \\
\text { Code }\end{array}$ \\
\hline 5 & $150 \mathrm{kWh}$ & $\begin{array}{c}\text { Couple Average } \\
\text { Consumption }\end{array}$ & $\mathrm{C} 1$ \\
\hline 10 & $300 \mathrm{kWh}$ & $\begin{array}{c}\text { Low Consumption } \\
\text { Family }\end{array}$ & $\mathrm{C} 2$ \\
\hline 5 & $500 \mathrm{kWh}$ & $\begin{array}{c}\text { High Consumption } \\
\text { Family }\end{array}$ & $\mathrm{C} 3$ \\
\hline
\end{tabular}

For the Shared Generation model, the choice of consumer units was chosen based on the Cooperative Simulator software options [17]. Table 2 lists the member's profiles according to the available options.

\section{A) Acquisition}

Table 3 presents the parameters used in the calculation of economic indicators for the acquisition business model.

Table 3 - PVS data (Own Source)

\begin{tabular}{|l|c|}
\hline \multicolumn{1}{|c|}{ Parâmetros } & Valores \\
\hline PVS Power (B1) & $1,83 \mathrm{kWp}$ \\
\hline PVS Power (B3) & $5,37 \mathrm{kWp}$ \\
\hline $\begin{array}{l}\text { Average annual irradiance for } \\
\text { Goiânia-GO }\end{array}$ & $5,41 \mathrm{hsp}$ \\
\hline Yearly Variability & $1,0 \%$ \\
\hline $\begin{array}{l}\text { Annual Drop in Yield } \\
\text { Performance }\end{array}$ & $0,70 \%$ \\
\hline $\begin{array}{l}\text { Number of Inverter Exchanges } \\
\text { (year 15) }\end{array}$ & 1 \\
\hline Performance ratio & $70 \%$ \\
\hline
\end{tabular}

\begin{tabular}{|l|c|}
\hline Annual O\&M Costs & $0,93 \%$ of INV \\
\hline Price of Energy Tariff & $0,87 \mathrm{R} \$ / \mathrm{kWh}$ \\
\hline $\begin{array}{l}\text { Annual Adjustment of Energy } \\
\text { Taxes }\end{array}$ & $5,31 \%$ a.a. \\
\hline PVS Cost (B1)* & $\mathrm{R} \$ 11.312,51$ \\
\hline PVS Cost (B3)* & $\mathrm{R} \$ 29.613,22$ \\
\hline Inverter percentage cost & $5,85 \%$ a.a. \\
\hline Average inflation per year & $10 \%$ a.a. \\
\hline $\begin{array}{l}\text { Minimum Attractiveness Rate } \\
\text { Return (MARR) }\end{array}$ & \\
\hline
\end{tabular}

*values confirmed by Greener research [18]

The results for the acquisition model are shown at Table 4.

Table 4 - Results for B1 and B3 and Acceptability criteria Acquisition Model

\begin{tabular}{|c|c|c|c|}
\hline Indicators & UC B1 & UC B3 & Decision \\
\hline NPV (R\$) & 8.910 & 44.233 & Accepted \\
\hline IRR (\% a.a.) & $17 \%$ & $23 \%$ & Accepted \\
\hline IL & $58 \%$ & $77 \%$ & Accepted \\
\hline Payback (years) & 6,4 & 4,8 & Accepted \\
\hline LCOE (R \$ /Wh) & 0,51 & 0,21 & Accepted \\
\hline
\end{tabular}

According to table 4, the UC projects analyzed for the acquisition model must be accepted with a reasonable safety margin, since all indicators were favorable to the acceptance of the projects, because in both cases:

NVP was positive; IRR higher than MARR (10\%); IL greater than $0 \%$, Payback less than project life (25 years) and LCOE lower than current rates (R \$ $0.87 / \mathrm{kwh})$.

\section{B) Third Part / Rent}

For the Rent model, the same consumer units as the acquisition model (B1 and B3) were considered. According to [16] the contract between the parties can be in three ways, namely rent, lease or PPA. In rent, the user pays a monthly amount proportional to the savings generated, but at the end of the contract, the SFV does not become the property of the user. Whereas in leasing, at the end of the contract, or even during this, the property (SFV) can be purchased by the lessee. PPA contracts, usually longer term (over 10 years) get their revenue directly from the sale of $\mathrm{kWh}$ (energy) it is noteworthy that this model is not yet possible in Brazil. The following case is the one with a rental contract.

As shown in [15], the revenue amounts for the SPV owner in this model may range from $90 \%$ to $70 \%$ of the revenue generated for the duration of the contract. Expenses are according to equation (8). The results presented are from the rent model. Table 4 shows the results.

Table 5 - Results B1 and B3 and Acceptability criteria - Rent Model

\begin{tabular}{|c|c|c|c|}
\hline Indicators & CU B1 & CU B3 & Decision \\
\hline NVP $(\mathrm{R} \$)$ & 305 & 18.981 & Accept \\
\hline
\end{tabular}




\begin{tabular}{|c|c|c|c|}
\hline IRR (\% a.a.) & $10 \%$ & $16 \%$ & Accept \\
\hline IL & $48 \%$ & $72 \%$ & Accept \\
\hline Payback $($ Years $)$ & 10,1 & 6,9 & Accept \\
\hline LCOE $(\mathrm{R} \$ / \mathrm{kWh})$ & 0,51 & 0,21 & Accept \\
\hline
\end{tabular}

In the rent model, we noticed that for consumer unit B1, the indicators indicated an acceptability of the business with little profit margin, since the IRR equaled the MARR, and the IL above $0 \%$. We also noticed a NPV very close to zero. Payback is long term (over 10 years). For B3 the indicators point to a positive return on investment with a good margin.

\section{C) Shared Generation}

Table 6 summarizes the results found for the economic viability criteria for the Shared Generation business model case.

Tabela 6 - Results for C1, C2 e C3 and Acceptability criteria Shared Solar Generation

\begin{tabular}{|c|c|c|c|c|}
\hline Indicators & C1 & C2 & C3 & Decision \\
\hline NVP (R\$) & 1.1592 & 4.784 & 52.714 & Accept \\
\hline IRR (\%a.a.) & $10,46 \%$ & $10,48 \%$ & $15,63 \%$ & Accept \\
\hline IL & $28 \%$ & $29 \%$ & $51 \%$ & Accept \\
\hline $\begin{array}{c}\text { Payback } \\
\text { (Years) }\end{array}$ & 10,3 & 7,4 & 8,2 & Accept \\
\hline $\begin{array}{c}\text { LCOE (R\$ } \\
\text { /kWh) }\end{array}$ & 1,11 & 0,92 & 0,76 & $\begin{array}{c}\text { Accept for } \\
\text { C3 }\end{array}$ \\
\hline
\end{tabular}

In the shared generation model, there is a large share of the value of the land for the construction of the plant, since it is larger. The results for consumer units $\mathrm{C} 1$ and $\mathrm{C} 2$ were not favorable considering the LCOE above the energy tariff value (0.87), another disadvantage for consumers $\mathrm{C} 1$ and $\mathrm{C} 2$ are the IRR values that are very close to the MARR $(10 \%)$.

\section{Conclusions}

This work presented for three business models an economic viability analysis, and for most of the presented configurations, the projects were viable. A constant was noted, the bigger the system the smaller the Payback and the larger the NPV. At this point larger systems tend to be, in any model, more profitable over time.

Improved technology and ease of importation or manufacturing within the country has reduced the initial costs of installing PVS in Brazil, so the cases here presented, regarding small photovoltaic generation, once considering the long term investment (over 10 years) is proving economically viable.

Only for Shared Generation the projects of small and medium size UCs proved unfeasible, but this may be due to the composition chosen for the simulation among other factors such as the price of land acquisition that is one of the software inputs.

The acquisition model is superior in return to other models because it has better indicators such as higher NPV value and shorter payback time. It would be advisable to buy an SFV or rent a system until one can invest in the purchase.

It is noteworthy that the variables used in the calculations may be different for other regions of the country and therefore the results are specific to the systems studied here.

\section{Acknowledgments}

Gratitude to the Solar Movement team and the Enel Distribuição Goiás planning team is hereby acknowledged for providing important data and information that was used in the research. I also thank my friend Murilo L. Magalhães for his contributions and friendship during the writing process of this article.

\section{References}

[1] Geissdoerfer, M., Vladimirova, D., \& Evans, S. (2018). Sustainable business model innovation: A review. Journal of cleaner production, 198, 401-416.

[2] Huijben, J. C., \& Verbong, G. P. (2013). Breakthrough without subsidies? PV business model experiments in the Netherlands. Energy Policy, 56, 362-370.

[3] Schoettl, J., \& Lehmann-Ortega, L. (2011). Photovoltaic business models: threat or opportunity for utilities. Handbook of research on energy entrepreneurship, 1, 145-171.

[4] Osterwalder, A., \& Pigneur, Y. (2013). Business model generation: inovação em modelos de negócios. Alta Books Editora.

[5] Richter, M. (2013). Business model innovation for sustainable energy: German utilities and renewable energy. Energy Policy, 62, 1226-1237.

[6] Kind, P. (2013). Disruptive challenges: financial implications and strategic responses to a changing retail electric business. Edison Electric Institute.

[7] R. E. N. Members, Renewables 2019 Global Status Report. 2019.

[8] Frantzis, L., Graham, S., Katofsky, R., \& Sawyer, H. (2008). Photovoltaics business models (No. NREL/SR-581-42304). National Renewable Energy Lab.(NREL), Golden, CO (United States).

[9] ANEEL (2012). Resolução normativa 482. Avaliable at <http://www2.aneel.gov.br/cedoc/ren2012482.pdf〉. Avaliable at http://www2.aneel.gov.br/cedoc/ren2015687.pdf > .

[11] Huijben, J. C., \& Verbong, G. P. (2013). Breakthrough without subsidies? PV business model experiments in the Netherlands. Energy Policy, 56, 362-370.

[12] Casarotto Filho, N., \& Kopittke, B. H. (1994). Análise de investimentos. Atlas.

[13] BRITO, P. (2011). Análise e viabilidade de projetos de investimentos. 4. reimpr. São Paulo: Atlas.

[14] EPE - Empresa de Pesquisa Energética. Balanço Energético Nacional 2018 (BEM 2018) - Ano base 2017. EMPRESA DE PES- QUISA ENERGÉTICA. Avaliable at $<$ http://www.epe.gov.br>.

[15] Diniz, J. Metodologia para análise de investimento em sistemas fotovoltaicos considerando parâmetros de incerteza e métricas de risco. Universidade Federal de Minas Gerais. 2017. [16] Eu-Wide Solar PV Business Models 2016. Avaliable athttps://www.solarpowereurope.org/eu-wide-solar-pvbusiness-models/.

[17] K. Schneider, M. O. M. Oliveira, P. S. Manoel, C. Japp, R. Rüther. Web Tool For Early Stages Of Techno-Economical Analysis Of Shared Solar Cooperatives In The Brazilian Context, 2019.

[18] Estudo Estratégico: Mercado Fotovoltaico GD Brasil $1^{\circ}$ Semestre $2019 . \quad$ Avaliable at: thttp://greener.greener.com.br/estudo-gd-1sem2019. 